\title{
Little auks buffer the impact of current Arctic climate change
}

\author{
David Grémillet ${ }^{1,2, *}$, Jorg Welcker ${ }^{3}$, Nina J. Karnovsky ${ }^{4}$, Wojciech Walkusz ${ }^{5,6}$, \\ Margaret E. Hall ${ }^{7}$, Jérôme Fort ${ }^{8}$, Zachary W. Brown ${ }^{4}$, John R. Speakman ${ }^{9}$, \\ Ann M. A. Harding ${ }^{10}$
}

${ }^{1}$ Centre d'Ecologie Fonctionnelle et Evolutive, UMR5175, CNRS-INEE, 1919 route de Mende, 34293 Montpellier Cedex 5, France

${ }^{2}$ Percy FitzPatrick Institute, DST/NRF Centre of Excellence, University of Cape Town, Rondebosch 7701, South Africa

${ }^{3}$ Norwegian Polar Institute, Fram Centre, 9296 Tromsø, Norway

${ }^{4}$ Pomona College, Department of Biology, 175 W. Sixth Street, Claremont, California 91771, USA

${ }^{5}$ Institute of Oceanology, Polish Academy of Sciences, Powsta ców Warszawy 55, 81-712 Sopot, Poland

${ }^{6}$ Freshwater Institute, Fisheries and Oceans, 501 University Crescent, Winnipeg, Manitoba R3T 2N6, Canada

${ }^{7}$ BirdWatch Ireland, Unit 20 Block D, Bullford Business Campus, Kilcoole, Co. Wicklow, Ireland

${ }^{8}$ Department of Bioscience, Aarhus University, Frederiksborgvej 399, 4000 Roskilde, Denmark

${ }^{9}$ School of Biological Sciences, University of Aberdeen, Tillydrone Avenue, Aberdeen AB24 2TZ, UK

${ }^{10}$ Alaska Pacific University, Environmental Science Department, 4101 University Drive, Anchorage, Alaska 99508, USA

\begin{abstract}
Climate models predict a multi-degree warming of the North Atlantic in the 21st century. A research priority is to understand the effect of such changes upon marine organisms. With 40 to 80 million individuals, planktivorous little auks Alle alle are an essential component of pelagic food webs in this region that is potentially highly susceptible to climatic effects. Using an integrative study of their behaviour, physiology and fitness at 3 study sites, we evaluated the effect of ocean warming on little auks across the Greenland Sea in 2005 to 2007. Contrary to our hypothesis, the birds responded to a wide range of sea surface temperatures via plasticity of their foraging behaviour, allowing them to maintain their fitness levels. Predicted effects of climate change are significantly attenuated by such plasticity, confounding attempts to forecast future effects of climate change using envelope models.
\end{abstract}

KEY WORDS: Behavioural plasticity - Envelope models - Global warming - North Atlantic · Pelagic food web $\cdot$ Zooplankton

\section{INTRODUCTION}

The earth's climate is warming, and this trend is amplified in Polar regions (Serreze et al. 2007, Graversen et al. 2008). Recent investigations confirm significant ocean warming in the Arctic sector of the North Atlantic (Polyakov et al. 2005, Walczowski \& Piechura 2006, Dmitrenko et al. 2008), and predict further increase of sea surface temperatures (SST) in this region across the 21st century (Karnovsky et al. 2010). One current challenge is to investigate the effect of these rapid changes upon organisms, food webs and biogeochemical cycles (Beaugrand et al. 2010). In this study, we tested the hypothesis that warmer surface water conditions in the North Atlantic influence the morphology, physiology and behaviour of little auks Alle alle, as well as their fitness (reproductive output and survival). 
The little auk is a particularly well-suited study species in the context of climate change because it is an important component of the Arctic food web, and is likely to be significantly affected by changing sea temperatures. Little auks are the most numerous seabird in the North Atlantic (with an estimated population of 40 to 80 million individuals, Stempniewicz 2001 ), and consume up to $24 \%$ of local plankton production (Karnovsky \& Hunt 2002). They mainly feed on copepods, which are strongly affected by climate change, with a marked tendency for temperate, smaller-sized species to spread northwards (Beaugrand et al. 2009). Moreover, the little auk field metabolic rate is $70 \%$ higher than predicted by body mass, and they have very limited capacity to store fat. Consequently they are predicted to be particularly sensitive to altered feeding conditions (Harding et al. 2009a).

Here we used a natural experiment across the Greenland Sea to mimic forecasted ocean warming of the North Atlantic (see Fig. 1). This framework follows Wernberg et al. (2010), who successfully used synoptic, regional differences in SST to simulate forthcoming ocean warming and test the response of marine organisms to climate change. Such design also allowed further investigations, such as testing the evolutionary response of plants to climate change (Etterson \& Shaw 2001), and complies with Brown et al. (2011). In our study system, recent work showed a very strong link between summer SST within the foraging areas of little auks, species composition of local zooplankton communities, and the dietary preferences of the birds (Karnovsky et al. 2010), whereby colder water contained more larger copepods, which were also preferentially fed upon by little auks (Karnovsky et al. 2010). Conversely, birds had to feed on smaller, less profitable copepod species in warmer water. Comparing the ecophysiology of little auks from different colonies subject to contrasting SST regimes at one moment in time therefore allowed us to simulate the effect that increasing water temperatures might have on this Arctic species across the 21st century. Using this rationale we tested the hypothesis that higher summer SST would result in diminished little auk fitness, with the predictions that higher SST would modify little auk diet, foraging effort, provisioning rates, breeding success and adult survival.

\section{MATERIALS AND METHODS}

The study took place during the little auk breeding season (July) in 2005, 2006 and 2007 at Kap Höegh,
East Greenland $\left(70^{\circ} 43^{\prime} \mathrm{N}, 22^{\circ} 38^{\prime} \mathrm{W}\right.$, hereafter $\left.\mathrm{KH}\right)$, Hornsund, West Spitsbergen $\left(77^{\circ} 00^{\prime} \mathrm{N}, 15^{\circ} 22^{\prime} \mathrm{E}\right.$, hereafter HS), and Kongsfjorden, West Spitsbergen $\left(79^{\circ} 01^{\prime} \mathrm{N}, 12^{\circ} 25^{\prime} \mathrm{E}\right.$, hereafter $\left.\mathrm{KF}\right)$, respectively (Fig. 1). However, not all variables listed below were collected at all sites in all years (see Table 1 for details).

\section{Sea surface temperatures}

We estimated mean SST for the month of July (the little auk chick-rearing period) each year for an area of $\sim 4000 \mathrm{~km}^{2}$ adjacent to each colony, using satellite data provided by the EUMETSAT Ocean and Sea Ice Satellite Application Facility (OSI SAF; see Welcker et al. 2009a). The size of this sampling area was chosen so as to fully enclose little auk core foraging areas at sea, as determined from at-sea direct observations and recordings of foraging trip durations (Karnovsky et al. 2010, Welcker et al. 2009a). Mean July SST was calculated by averaging daily means based on all data points available within the selected areas.

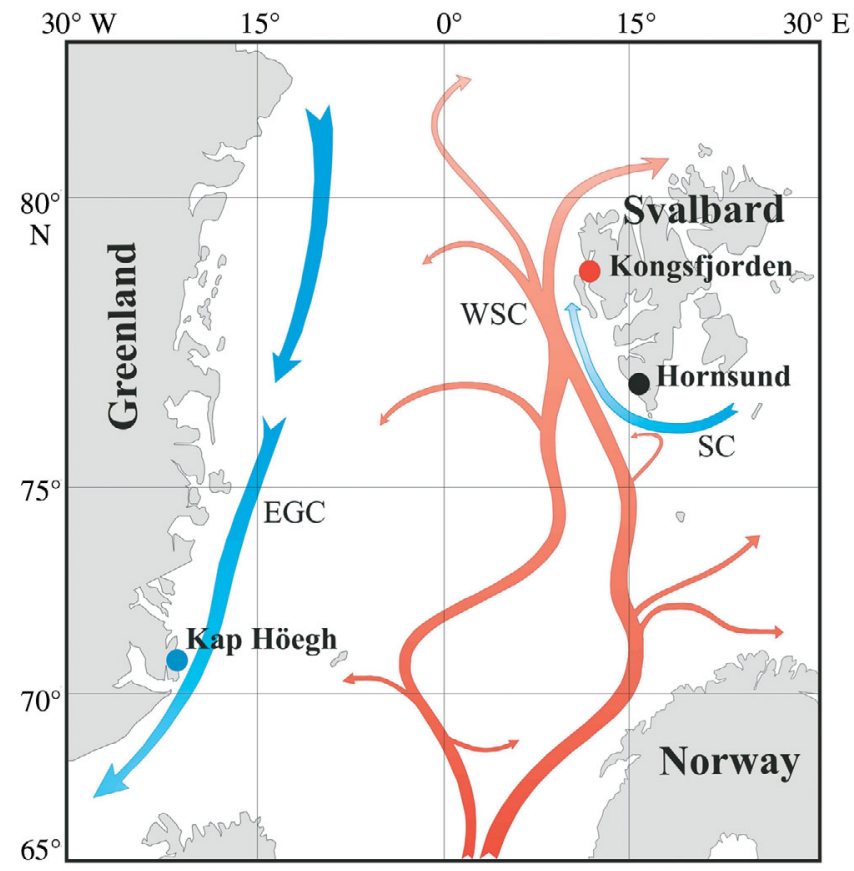

Fig. 1. Position of the 3 study sites in the Greenland Sea. The East Greenland Current (ECG) maintains cold water conditions off Kap Höegh. Off Hornsund, the cold Sørkapp Current (SC) and the warm West Spitsbergen Current (WSC) provide intermediate water temperature conditions, whereas the WSC forces warmer Atlantic water into the Kongsfjorden area. The northernmost study site is therefore the warmest in terms of sea-surface temperature 


\section{Diet}

Prey items caught by adults breeding at all colonies and brought back to their chicks were collected and identified following Harding et al. (2009a). Briefly, breeding little auks were caught in noose carpets at the colony, and zooplankton that they collected at sea were scooped out of their gular pouch. Individual plankton meals were stored in $4 \%$ borax-buffered formaldehyde solution, and examined under a stereomicroscope. Prey items were identified to species level wherever possible, and remaining taxa were identified to the lowest possible taxonomical level. Calanus species were identified according to Kwaśniewski et al. (2003). Abundant taxa were enumerated from subsamples while large and rare individuals from different taxa were counted for the whole diet sample.

\section{Foraging effort}

We determined foraging parameters of little auks in 2007 at the 3 study sites using time-depth-recorders (TDR). The TDRs used were Cefas G5 Data Storage Tags (CTL) with $8 \mathrm{MB}$ of memory, and were cylindrical in shape with a rounded tip to minimise water resistance. The TDRs weighed $2.7 \mathrm{~g}$ in air, or $1.6 \%$ of the average initial mass of experimental birds. These devices have no measurable effect on little auk energy consumption (Harding et al. 2009a). We programmed the TDRs to record temperature and pressure every $5 \mathrm{~s}$ for up to $5 \mathrm{~d}$. When the birds dived below $1.5 \mathrm{~m}$, temperature and pressure readings were made every $0.2 \mathrm{~s}$ for the duration of the dive. TDRs were attached ventrally using Loctite ${ }^{\circledR}$ glue to adult little auks raising 1 to $18 \mathrm{~d}$ old chicks. Birds were caught either by hand in accessible nest crevices, or using noose carpets on rock surfaces. Handling lasted $<10 \mathrm{~min}$ in all cases and data loggers were deployed for a maximum of $5 \mathrm{~d}$. Recorded data were analysed following Harding et al. (2009a) so as to extract (1) foraging trip durations, (2) total flight time per foraging trip, (3) total number of dives per $24 \mathrm{~h}$ and (4) the proportion of time (\%) spent underwater per $24 \mathrm{~h}$.

\section{Chick feeding rates}

To estimate chick feeding rates at $\mathrm{KH}$ and $\mathrm{HS}$, breeding adults were individually marked with colour rings or picric acid, and their nest sites were observed non-stop for 24 to $48 \mathrm{~h}$ periods, allowing exact recording of nest visits. In addition to direct observations, miniature radio-transmitters (Holohil Systems and Biotrack) attached to breeding adults were also used to determine chick feeding rates at KF (see Welcker et al. 2009b for details).

\section{Daily energy expenditure}

Daily energy expenditure (DEE in $\mathrm{kJ} \mathrm{d}^{-1}$ ) of little auks breeding at $\mathrm{KH}$ and $\mathrm{KF}$ was estimated using the doubly labelled water (DLW) technique, following Welcker et al. (2009b) and the single sample method. Breeding adults caught at the nest or on the colony were weighed, given an intraperitoneal injection of DLW, colourmarked and released immediately. A single blood sample was drawn upon recapture, within 24 to $72 \mathrm{~h}$. Isotopic dosages, laboratory analyses and DEE calculations followed Speakman (1997) and were conducted as detailed by Welcker et al. (2009b).

\section{Breeding performance}

Little auks raise a single chick in an underground nest crevice. During chick rearing, each studied nest was monitored every $3 \mathrm{~d}$. Chick growth 
rates and fledging mass were only recorded at $\mathrm{KH}$ and HS using a Pesola balance (precision $\pm 2.0 \mathrm{~g}$ ) because nests were out of reach at $\mathrm{KF}$, and only the presence/absence of the chick was determined using light-scopes (Moritex Europe). Fledging mass was the last measurement taken prior to a chick's departure from the colony, and only chicks that had reached $20 \mathrm{~d}$ when they disappeared from the nest were considered fledged (Harding et al. 2004). Fledging age and maximum fledging success (defined as the number of chicks fledged or reaching $20 \mathrm{~d}$ per number hatched) were calculated for a subsample of nests at each of the 3 colonies.

\section{Adult body condition and survival}

For all adults caught at the 3 colonies, we recorded body mass, headbill length and wing length, and these measurements were used to calculate an index of body condition (body mass corrected for structural size) as detailed in Harding et al. (2011). Adult survival rates of birds from KH and KF were determined using a capture-mark-recapture analysis. Briefly, at $\mathrm{KH}$, breeding adults $(\mathrm{n}=147)$ were caught in 2005 and individually marked with combinations of 3 colour rings and 1 metal ring. At KF, 299 birds were caught in 2006 and an additional 110 individuals in 2007, and marked in a similar way. Subsequent resighting sessions were conducted annually during the breeding season until 2009, with a minimum of $6 \mathrm{~d}$ per year and site. We used Cormack-Jolly-Seber (CJS) models implemented in the program MARK (White \& Burnham 1999) to estimate yearly survival rates. With our data, we were unable to separate mortality from permanent emigration; therefore, estimated survival rates reflect apparent survival rather than true survival (however, for simplicity, we refer to 'survival rates' in this paper). We fitted 2 sets of CJS models: (1) using the combined data from $\mathrm{KH}$ and $\mathrm{KF}$ to estimate yearly survival from 2006/07 to 2008/09 and to test for between-colony differences, and (2) using $\mathrm{KH}$ data only to estimate yearly survival in 2005/06 for which no data was available for KF.

We assessed the goodness-of-fit of the global model allowing for time and colony-specific survival (denoted as $\Phi$ ) and resighting probabilities (denoted as p) using the program U-CARE (Choquet et al. 2009). This model clearly did not fit the data $\left(\chi^{2}{ }_{4}=\right.$ $31.55, \mathrm{p}<0.001)$. Inspection of the component tests revealed that rejection of the CJS model was mainly based on Test 2.CT, indicating strong re- sighting heterogeneity (trap-happiness), especially in KF birds. We accounted for trap dependence by estimating different resighting probabilities for individuals that were seen versus not seen the previous year (Pradel 1993), denoted as $h$ in our models. The resulting model $\left\{\Phi_{\text {c.t. }}, p_{\text {c.t.h }}\right\}$, where $\mathrm{c}$ is colony and $t$ is time (year), fitted the data well $\left(\chi^{2}{ }_{2}\right.$ $=0.72, p=0.70$ ) and was used as the starting point for model selection based on Akaike's information criterion adjusted for small sample size $\left(\mathrm{AIC}_{\mathrm{c} i}\right.$ Anderson \& Burnham 1999). The goodness-of-fit test for the second dataset ( $\mathrm{KH}$ only) indicated that the CJS model fitted these data well $\left(\chi^{2}{ }_{3}=2.13, \mathrm{p}=\right.$ $0.55)$, thus the model $\left\{\Phi_{\mathrm{t}}, \mathrm{p}_{\mathrm{t}}\right\}$ was used as a starting point for this analysis. All possible models allowing survival probabilities to vary with time and/or colony and/or SST (including additive models) were examined. To account for model selection uncertainty we report survival estimates \pm SE based on model averaging (Burnham \& Anderson 2002; see Table 3).

\section{Further statistical analyses}

Differences in SST between years and sites were assessed using ANOVA. We used least squares linear regressions to test whether variation in our response variables across the different colonies and different years was related to differences in SST (Wernberg et al. 2010). This was done to assess the effect of SST on foraging effort (foraging trip duration, flight time, number of dives and time underwater per foraging trip), chick feeding rates and chick growth (peak mass, fledging mass and fledging age), daily energy expenditure and adult body condition. Data were log-transformed where necessary.

To examine the effect of SST on diet composition we used a 2-pronged approach. To account for the fact that these data contained many zeros (prey item not present in a sample) which cannot be accommodated with simple data transformations, we first fitted a generalised linear model with binomial errors to test whether SST affected the probability of a diet item (Calanus hyperboreus, C. glacialis and C. finmarchicus) to occur in a sample. In a second step, we then tested whether the proportion of these items in the diet was related to SST, excluding all zeros. Data were arcsine-transformed for this analysis.

Similarly, we used a generalised linear model with binomial error to assess the effect of SST on fledging success. All statistical analyses were performed using R 12.2. Means $(X)$ are provided \pm SD. 


\section{RESULTS}

We studied birds at 3 different localities in 2005 to 2007 (Fig. 1), where they foraged for zooplankton in surface waters $(<40 \mathrm{~m})$. SST in foraging areas off the 3 study sites differed substantially $\left(F_{2,121}=96.25, \mathrm{p}<\right.$ 0.001 ) and this difference was consistent across years $\left(F_{2,121}=2.03, \mathrm{p}=0.136\right)$. SST was lowest around KH $\left(X=0.39 \pm 0.29^{\circ} \mathrm{C}\right)$, intermediate around HS $(X=1.81$ $\left.\pm 0.18^{\circ} \mathrm{C}\right)$ and highest around $\mathrm{KF}\left(X=4.51 \pm 1.06^{\circ} \mathrm{C}\right)$. Cold areas of the Greenland Sea favour large copepod species (Calanus hyperboreus, 7 to $8 \mathrm{~mm}$ long), while warmer areas favour smaller ones $(C$. glacialis, 3 to $5 \mathrm{~mm}$ long and C. finmarchicus, 2 to $4 \mathrm{~mm}$ long; Karnovsky et al. 2010). Studying food loads brought back to the colonies by breeding parents, we found that little auks fed primarily on copepods ( 68 to $97 \%$ ). Diet was adjusted according to local copepod availability, with birds preferentially feeding on large copepods in the cold water off Greenland (Table 2, Fig. 2A) and on small copepods in warm water off Spitsbergen (Table 2, Fig. 2B,C). Birds also nearly doubled their foraging trip duration for warm compared to colder water, and nearly tripled their foraging flight time (Table 2, Fig. 3AB). However, the number of dives per foraging trip and time spent underwater per foraging trip was not significantly correlated with SST (Table 2, Fig. 3C,D). This indicates that copepod swarms were similarly profitable once the birds were underwater; however, little auks breeding near warm waters had to spend more time on the wing to reach them. Despite enhanced foraging activity over warm water, little auk daily energy expenditures estimated by the DLW method were unaffected by SST (Table 2). We speculate that little auks might buffer higher foraging costs by reducing their energetic investment into other activities, for instance by decreasing patrolling flight over the breeding site outside their actual foraging trips (a common and energetically costly behaviour in this species).

Crucially, plasticity in foraging behaviour allowed birds to balance their energy budgets, and to maintain chick provisioning rates across the SST range (Table 2). Chick growth curves were consequently similar when parents foraged in cold and warm water (Fig. 4). In warmer water, chicks tended to reach higher peak mass and to fledge later (Table 2; but note the very low regression coefficients for both relationships: 0.048 and 0.040 , respectively), yet the essential parameters of fledging mass and fledging success were unaffected by SST across the 3 study sites (Table 2). Further, there was no effect of SST on the body condition index of breeding little auks (Table 2, Fig. 5), nor on adult survival (Table 3, Fig. 6). There was nonetheless substantial interannual variability in adult survival especially at $\mathrm{KH}$, strongly suggesting that this variable might also be driven by events occurring outside of the breeding season (Fort et al. 2009).

Table 2. Statistical analyses testing the potential link between sea surface temperature (SST) and different seabird parameters. Statistical tests are based on least squares linear regressions except for diet probabilities (probability of a prey item occurring in a diet sample) and breeding success for which a relationship with SST was assessed by generalised linear models with binomial errors. See 'Materials and methods' for details. Significant p-values $(p<0.005)$ in bold. FMR: field metabolic rate. ${ }^{a} z$-value

\begin{tabular}{|c|c|c|c|c|c|}
\hline Variable & Estimate $\pm \mathrm{SE}$ & $t$ & df & $\mathrm{p}$ & $\mathrm{R}^{2}$ \\
\hline Diet proportion Calanus hyperboreus & $-0.085 \pm 0.015$ & -5.841 & 117 & $<0.0001$ & 0.226 \\
\hline Diet proportion C. glacialis & $0.087 \pm 0.017$ & 5.267 & 192 & $<0.0001$ & 0.126 \\
\hline Diet proportion C. finmarchicus & $0.022 \pm 0.004$ & 5.093 & 186 & $<0.0001$ & 0.122 \\
\hline Diet probability C. hyperboreus & $-1.298 \pm 0.229$ & $-5.677^{\mathrm{a}}$ & 193 & $<0.0001$ & \\
\hline Diet probability C. glacialis & $2.378 \pm 0.938$ & $2.536^{\mathrm{a}}$ & 193 & 0.011 & \\
\hline Diet probability C. finmarchicus & $0.354 \pm 0.107$ & $3.313^{\mathrm{a}}$ & 193 & $<0.0001$ & \\
\hline Foraging trip duration & $0.930 \pm 0.264$ & 3.520 & 22 & 0.0019 & 0.331 \\
\hline Flight time per foraging trip & $0.960 \pm 0.142$ & 6.775 & 22 & $<0.0001$ & 0.661 \\
\hline Dives per foraging trip & $-0.552 \pm 14.145$ & -0.039 & 22 & 0.97 & 0.045 \\
\hline Time underwater per trip & $0.093 \pm 0.195$ & 0.477 & 22 & 0.638 & 0.035 \\
\hline FMR & $-4.072 \pm 9.657$ & -0.422 & 68 & 0.675 & 0.003 \\
\hline Chick feeding & $-0.004 \pm 0.017$ & 0.258 & 118 & 0.797 & 0.0006 \\
\hline Chick peak mass & $0.028 \pm 0.011$ & 2.454 & 120 & 0.0155 & 0.048 \\
\hline Chick fledging age & $0.008 \pm 0.003$ & 2.873 & 197 & 0.0045 & 0.040 \\
\hline Chick fledging mass & $0.440 \pm 1.160$ & 0.380 & 120 & 0.705 & 0.001 \\
\hline Fledging success & $-0.026 \pm 0.087$ & $-0.304^{\mathrm{a}}$ & 339 & 0.761 & \\
\hline Condition & $0.278 \pm 0.146$ & 1.908 & 1041 & 0.057 & 0.003 \\
\hline
\end{tabular}



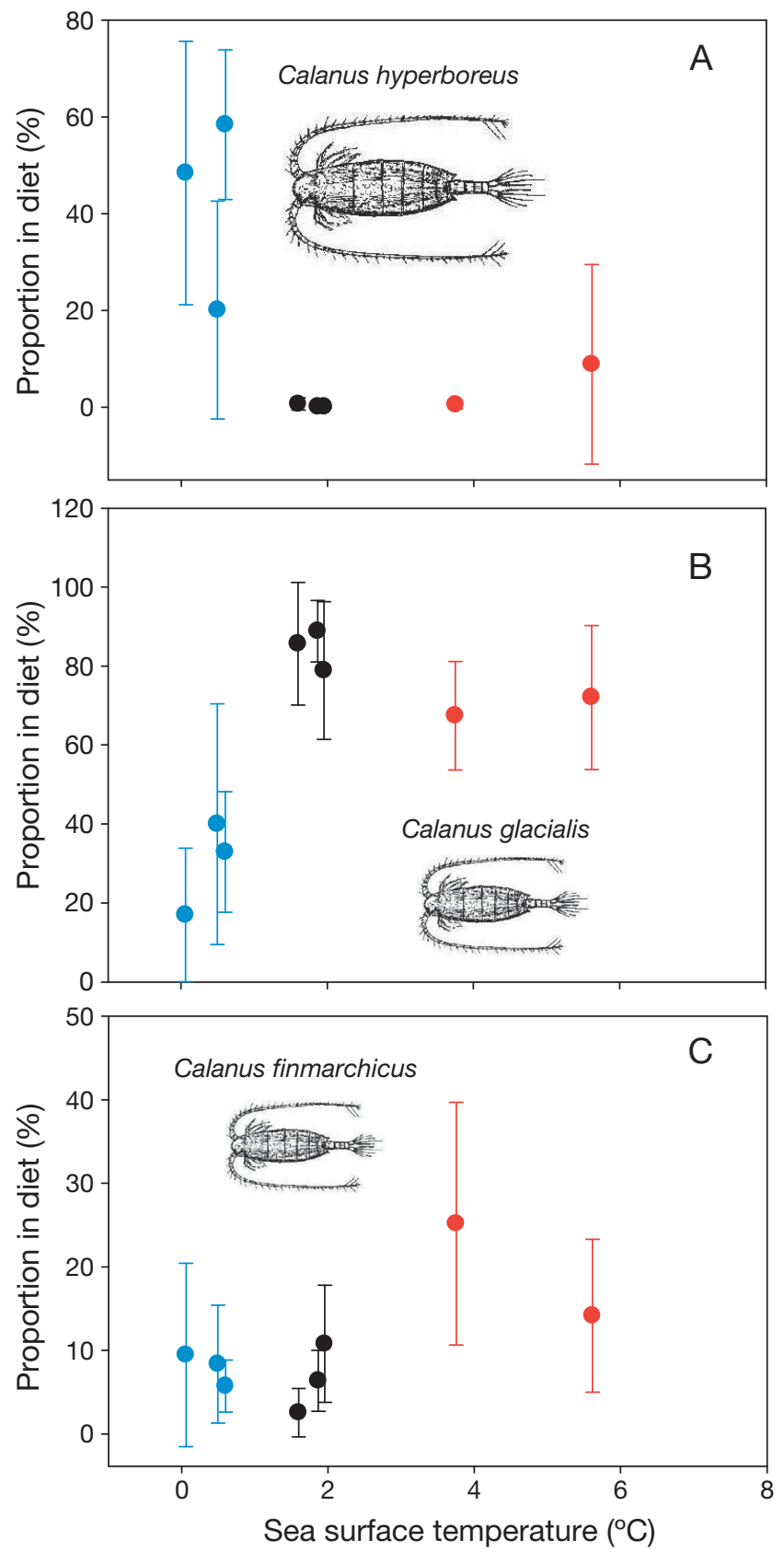

Fig. 2. Alle alle. Feeding preferences on different copepods, means \pm SE. (A) Calanus hyperboreus ( 7 to $8 \mathrm{~mm}$ long), (B) C. glacialis (3 to $5 \mathrm{~mm}$ long), (C) C. finmarchicus (2 to $4 \mathrm{~mm}$ long). Blue: Kap Höegh; black: Hornsund; red: Kongsfjorden. See Table 2 for detailed statistics

\section{DISCUSSION}

Using our comparative framework across the Greenland Sea, we reject the hypothesis of a general influence of current Arctic Ocean warming on the fitness of the highly abundant, ecologically important little auk. During our study, the overall SST differen- tial measured across study sites was $>5^{\circ} \mathrm{C}$. In oceanographic terms, this is a major difference, which is predicted to cause vast changes in zooplankton community composition (Beaugrand et al. 2009). Such a $\triangle \mathrm{SST}$ is close to the maximum change of $7^{\circ} \mathrm{C}$ predicted for the North Atlantic in the 21st century (Karnovsky et al. 2010). We therefore consider this $\Delta$ SST and our study design adequate to test the effect of ocean warming on little auk ecophysiology.

One potential limitation of our study design is that we studied birds of the same species exposed to contrasted environmental conditions which, however, attended breeding colonies hundreds of $\mathrm{km}$ apart. There is therefore the possibility that observed patterns are not due to species-specific plasticity, but to micro-evolution of distinct groups within a metapopulation. However, a study of North Atlantic Alcidae (the seabird family including little auks) demonstrated that distant breeding populations of the same species are genetically highly homogeneous, strongly suggesting intense genetic mixing, even between the most distant breeding sites (Riffaut et al. 2005). Furthermore, recent population genetic analyses of little auks breeding across the North Atlantic also show very high genetic mixing among populations (K. Wojczulanis-Jakubas et al. unpubl.). It is, therefore, reasonable to assume that birds from our 3 study sites belong to the same population, with similar potential for ecophysiological plasticity.

Moreover, our analyses focused on the effect of ocean surface warming, which is in line with the major research objectives of the inter-governmental panel on the effect of climate change (IPCC, working group II) for their forthcoming 2014 assessment report. However, a series of other biotic and abiotic environmental variables may potentially affect the ecophysiology and fitness of seabirds such as little auks (e.g. wind and air temperature, competition, see Fort et al. 2009), and might explain the wide numerical range recorded for some variables, such as breeding success (61 to 98\%) or annual adult survival (61 to $92 \%$; Fig. 6). Furthermore, some results specific to the HS site, which deviate from the general, significant trends presented in Fig. 3C,D, suggest the existence of locally different functional relationships between SST and seabird foraging parameters. These aspects deserve further investigation, yet there is compelling evidence that water temperature is the single most important environmental parameter within oceanic ecosystems, and that its rapid increase is currently triggering a complete reorganisation of the plankton community upon which little auks feed in the North Atlantic (Beaugrand et al. 2009, 2010). 

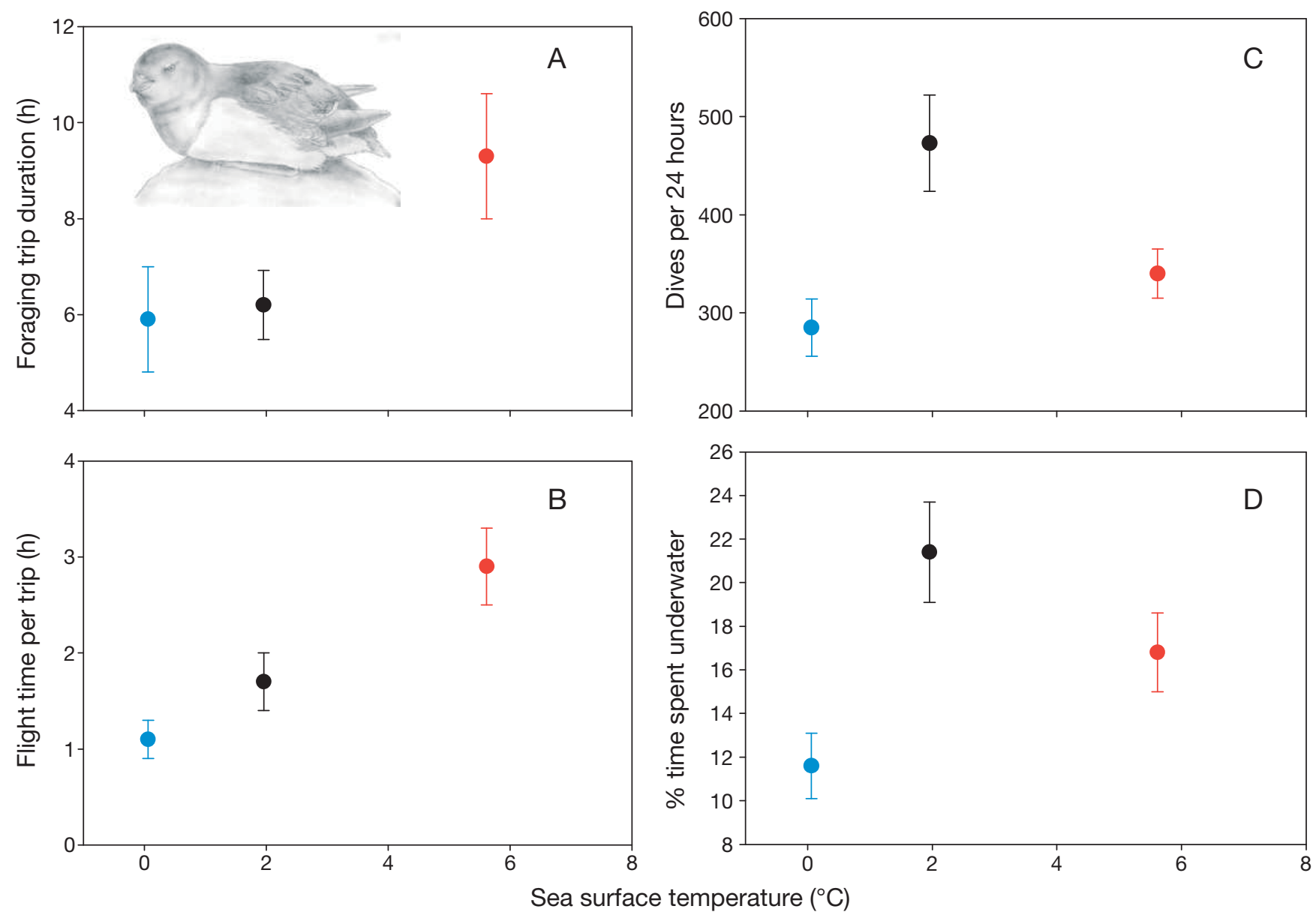

Fig. 3. Alle alle. Influence of sea surface temperature (SST) upon (A) foraging trip duration, (B) flight time per foraging trip, (C) total number of dives per $24 \mathrm{~h}$ and (D) proportion of time spent underwater (see Table 2 for statistical details). Data were recorded in 2007 (blue: Kap Höegh, black: Hornsund, and red: Kongsfjorden) using time-depth recorders deployed between 1.3 and $4.7 \mathrm{~d}(X=3 \pm 1)$, recording between 2 and 14 foraging trips $(X=7 \pm 3)$ for each bird

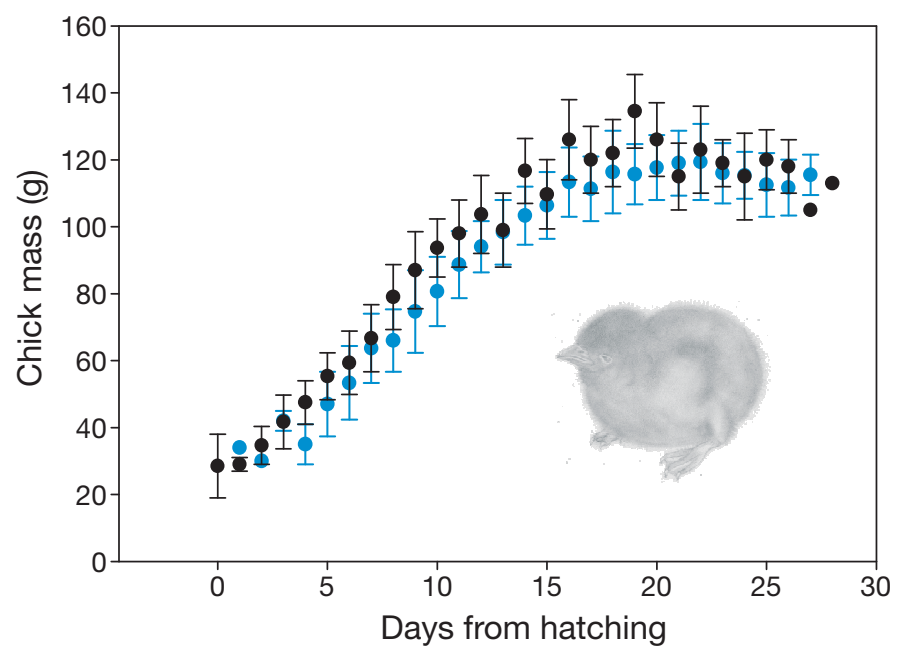

Fig. 4. Alle alle. Average growth curves of chicks in 2005 to 2007 at (blue) Kap Höegh (cold water) and (black) Hornsund (warm water). See Table 2 for detailed statistics

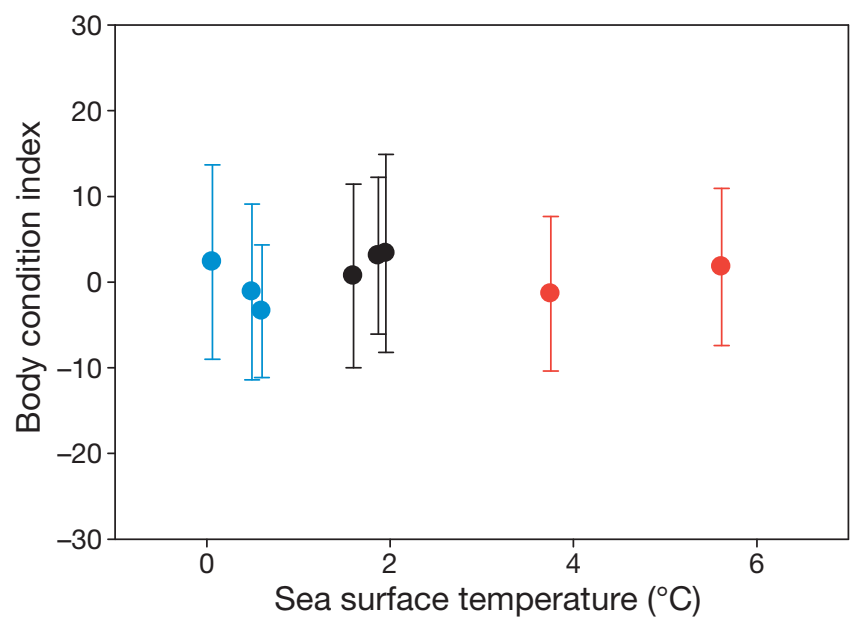

Fig. 5. Alle alle. No effect of water temperature on the body condition index of adults breeding at 3 Greenland Sea colonies (blue: Kap Höegh, black: Hornsund, and red: Kongsfjorden) in 2005 to 2007 . See Table 2 for detailed statistics 
Table 3. Survival modelling for adult little auks from Kap Höegh (KH) and Kongsfjorden (KF) in 2006 to 2009. The 5 most parsimonious models according to $\mathrm{AIC}_{\mathrm{c}}$ are given out of the possible models allowing survival probabilities to vary with time and/or colony and/or sea surface temperature (SST) that were tested. $\Phi=$ apparent (yearly) survival; $\mathrm{p}=$ resighting probability; $\mathrm{c}=$ colony $(\mathrm{KH}$ vs. $\mathrm{KF}) ; \mathrm{t}=$ time; $\mathrm{h}=$ resighting heterogeneity (h1 extending $1 \mathrm{yr}, \mathrm{h} 2$ extending 2 yr)

\begin{tabular}{|lcccccc|}
\hline$\Phi$ & $\mathrm{p}$ & Deviance & $\begin{array}{c}\text { No. } \\
\text { parameter }\end{array}$ & $\Delta \mathrm{AIC}_{\mathrm{c}}$ & $\begin{array}{c}\mathrm{AIC} \\
\text { weight }\end{array}$ & $\begin{array}{c}\text { Model } \\
\text { likelihood }\end{array}$ \\
\hline $\mathrm{C} \times \mathrm{t}$ & $\mathrm{h} 2$ & 856.71 & 9 & 0 & 0.424 & 1 \\
$\mathrm{C} \times \mathrm{t}$ & $\mathrm{C}+\mathrm{h} 2$ & 855.59 & 10 & 0.909 & 0.269 & 0.635 \\
$\mathrm{c} \times \mathrm{t}$ & $\mathrm{h} 1$ & 860.21 & 8 & 1.461 & 0.204 & 0.482 \\
$\mathrm{C} \times \mathrm{t}$ & $\mathrm{c}+\mathrm{h} 1$ & 859.57 & 9 & 2.860 & 0.102 & 0.239 \\
$\mathrm{C} \times \mathrm{SST}$ & $\mathrm{h} 2$ & 878.70 & 7 & 17.93 & 0.00005 & 0.0001 \\
\hline
\end{tabular}

change (Bradshaw \& Holzapfel 2006, Charmantier et al. 2008, Kearney et al. 2009). A wide range of studies have identified correlations between climate variables and the distribution, phenology, and dynamics of wild populations (Parmesan \& Yohe 2003). Such evidence has played a key role in demonstrating the ecological consequences of ongoing climate change, and these correlations have been used to design climate envelope models to forecast future trends (Sommer et al. 2010). Behavioural plasticity demonstrated here significantly attenuates the effect of antici-

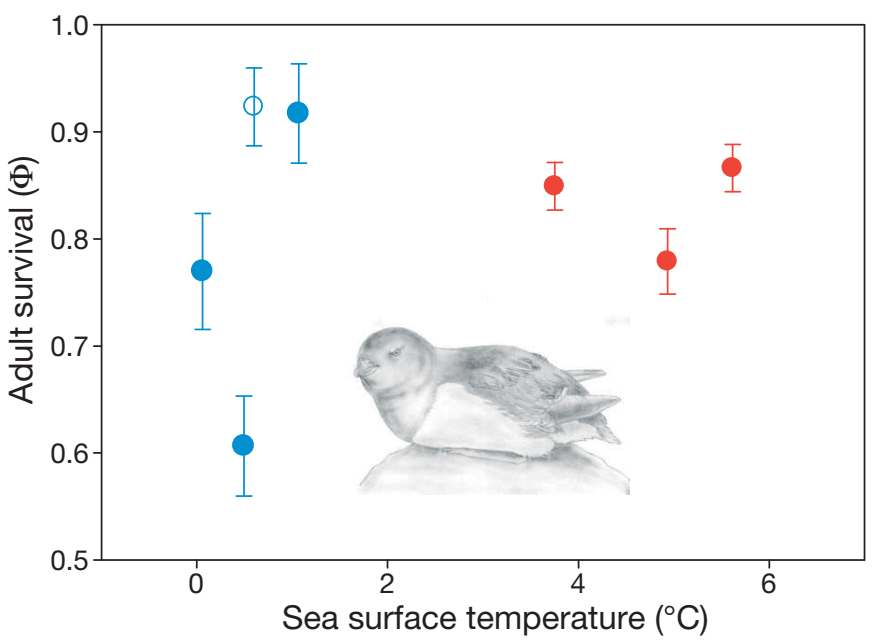

Fig. 6. Alle alle. No effect of water temperature on the survival rate of adults breeding at 2 Greenland Sea colonies (blue: Kap Höegh, red: Kongsfjorden) in 2006 to 2009. The best model including sea surface temperature (SST) was 17.9 AICc units less well supported than the best model without an effect of SST. Note substantial annual variation in adult survival at Kap Höegh (open symbol: 2005 data point). See Table 3 for detailed statistics

Beyond these caveats, our findings are important for a better understanding of the short-term plastic responses of marine polar organisms to rapid ocean warming, for studies modelling the ecological influence of current and future Arctic climate change, and for the design of ecological monitoring of a warming Arctic (Grémillet \& Charmantier 2010). In particular, our study is among the first to assess the capacity of a marine predator to buffer the consequences of climate change. Our conclusions are coherent with those of recent investigations which stress that behavioural plasticity is the primary mechanism by which animals deal with the consequences of climate pated climatic effects, undermining the ability of envelope models to realistically mirror future trends. Our data, therefore, underline recent criticism of such models (Morin \& Thuiller 2009), and support the proposed development of mechanistic models as an alternative (Buckley et al. 2010). These novel tools are powerful and can be better validated, yet they require vast amounts of information relative to the functional ecology of the species concerned. In this context, our detailed study of the ecophysiology of little auks facing the consequences of climate change is a crucial step towards developing mechanistic models of the effect of climate change upon marine organisms (Fort et al. 2009).

During the study period, little auks maintained their fitness despite contrasting ocean surface temperatures and copepod availability across the Greenland Sea. This indicates that they are successful at dealing with the influence of current climate change in the Arctic. However, recent experiments and modelling strongly suggest that little auks function close to their maximum foraging capabilities, and will not cope with further degradation of their feeding conditions (Karnovsky et al. 2010). Indeed, breeding little auks for which flight costs had been artificially augmented had significantly lower body masses, and fledged considerably lighter chicks (Harding et al. 2009b). Consequently, we argue that even if little auks seem currently able to buffer the consequences of climate change in the North Atlantic, such abilities will not extend indefinitely. Following rapid North Atlantic warming, the $5^{\circ} \mathrm{C}$ isotherm will soon reach the East Greenland coast at $70^{\circ} \mathrm{N}$ and West Spitsbergen at $80^{\circ} \mathrm{N}$. This will not only exclude large Calanus hyperboreus copepods whose thermal preferendum lies between -2 and $+4{ }^{\circ} \mathrm{C}$ (Karnovsky et al. 2010), but may also favour 'southern invaders,' such 
as Metridia lucens, which are currently absent from the area. It remains to be tested whether little auks will manage to efficiently feed upon these organisms, an adaptation which will require morphological (bill shape), physiological (digestion) and behavioural plasticity. Understanding the limits of such plasticity is essential for the mechanistic modelling of climate effects on little auks and other organisms to achieve its potential.

Acknowledgements. This study was funded by the National Science Foundation (Grant 0612504 to N.J.K. and A.M.A.H. and Grant 0301469 to N.J.K.), the Research Council of Norway (MariClim, 165112/S30), and the French Polar Institute (IPEV Project 388 to D.G. and A.M.A.H.). All investigations were conducted under permits of the Governor of Svalbard, the Greenland Homerule Government, the Danish Ministry of Environment and Nature, and the Ethics Committee of the French Polar Institute. We thank all assistants for heroic Arctic field sessions in polar bear areas: A. Bailey, N. Baldwin, L. Borg, D. Buchner, S. Christensen-Dalsgaard, J. Creuwels, J. Delingat, A. Diederichs, K. Holser, L. McFadden, S. Natterer, R. Orben, V. Patil, M. Pella-Donnelly, E. Pettex, H. Routti, J. Schultner, N. Seifert and E. Weston. We are grateful to S. Patrick and A. Lescroël for statistical assistance and to M. Fort for illustrations.

\section{LITERATURE CITED}

Anderson DR, Burnham KP (1999) General strategies for the analysis of ringing data. Bird Study 46:S261-S270

> Beaugrand G, Luczak C, Edwards M (2009) Rapid biogeographical plankton shifts in the North Atlantic Ocean. Glob Change Biol 15:1790-1803

Beaugrand G, Edwards M, Legendre L (2010) Marine biodiversity, ecosystem functioning, and carbon cycles. Proc Natl Acad Sci USA 107:10120-10124

Bradshaw WE, Holzapfel CM (2006) Evolutionary response to rapid climate change. Science 312:1477-1478

Brown CJ, Schoeman DS, Sydeman WJ, Brander K and others (2011) Quantitative approaches in climate change ecology. Glob Change Biol 17:3697-3713

Buckley LB, Urban MC, Angilletta MJ, Crozier LG, Rissler LJ, Sears MW (2010) Can mechanism inform species' distribution models? Ecol Lett 13:1041-1054

Burnham KP, Anderson DR (2002). Model selection and multimodel inference: A practical information-theoretical approach, 2nd edn. Springer, New York

Charmantier A, McCleery RH, Cole LR, Perrins C, Kruuk LEB, Sheldon BC (2008) Adaptive phenotypic plasticity in response to climate change in a wild bird population. Science 320:800-803

Choquet R, Lebreton JD, Gimenez O, Reboulet AM, Pradel R (2009) U-CARE: Utilities for performing goodness of fit tests and manipulating capture-recapture data. Ecography 32:1071-1074

> Dmitrenko IA, Polyakov IV, Kirillov SA, Timokhov LA and others (2008) Toward a warmer Arctic Ocean: Spreading of the early 21st century Atlantic Water warm anomaly along the Eurasian Basin margins. J Geophys Res 113: C05023
Etterson JR, Shaw RG (2001) Constraint to adaptive evolution in response to climate change. Science 294:151-154 Fort J, Porter WP, Grémillet D (2009) Thermodynamic modelling predicts energetic bottleneck for seabirds wintering in the northwest Atlantic. J Exp Biol 212:2483-2490

Graversen RG, Mauritsen T, Tjernström M, Källen E, Svensson G (2008) Vertical structure of recent Arctic warming. Nature 451:53-56

> Grémillet D, Charmantier A (2010) Shifts in phenotypic plasticity constrain the value of seabirds as ecological indicators of marine ecosystems. Ecol Appl 20:1498-1503

> Harding AMA, Van Pelt TI, Lifjeld JT, Mehlum F (2004) Sex differences in little auk Alle alle parental care: transition from biparental to paternal-only care. Ibis 146:642-651

> Harding AMA, Egevang C, Walkusz W, Merkel F, Blanc S, Grémillet D (2009a) Estimating prey capture rates of a planktivorous seabird, the little auk (Alle alle), using diet, diving behaviour, and energy consumption. Polar Biol 32:785-796

> Harding AMA, Kitaysky AS, Hall ME, Welcker J and others (2009b) Flexibility in the parental effort of an Arcticbreeding seabird. Funct Ecol 23:348-358

> Harding AMA, Welcker J, Steen H, Hamer KC and others (2011) Adverse foraging conditions may impact body mass and survival of a high Arctic seabird. Oecologia 167:49-59

> Karnovsky NJ, Hunt GL Jr. (2002) Estimation of carbon flux to dovekies (Alle alle) in the North Water. Deep Sea Res II 49:5117-5130

> Karnovsky N, Harding AMA, Walkusz V, Kwaśniewski S and others (2010) Foraging distributions of little auks (Alle alle) across the Greenland Sea: Implications of present and future climate change. Mar Ecol Prog Ser 415: 283-293

> Kearney M, Shine R, Porter WP (2009) The potential for behavioral thermoregulation to buffer "coldblooded" animals against climate warming. Proc Natl Acad Sci USA 106:3835-3840

Kwa niewski S, Hop H, Falk-Petersen S, Pedersen G (2003) Distribution of Calanus species in Kongsfjorden, a glacial fjord in Svalbard. J Plankton Res 25:1-20

Morin X, Thuiller W (2009) Comparing niche- and processbased models to reduce prediction uncertainty in species range shifts under climate change. Ecology 90:1301-1313

Parmesan C, Yohe G (2003) A globally coherent fingerprint of climate change impacts across natural systems. Nature 421:37-42

> Polyakov IV, Beszczynska A, Carmack EC, Dmitrenko IA and others (2005) One more step toward a warmer Arctic. Geophys Res Lett 32:L17605, doi: 10.1029/2005GL023740

Pradel R (1993). Flexibility in survival analysis from recapture data: Handling trap-dependence. In: Lebreton JD, North PM (eds) Marked individuals in the study of bird population. Birkhäuser, Basel, p 29-37

Riffaut L, McCoy KD, Tirard C, Friesen VL, Boulinier T (2005) Population genetics of the common guillemot Uria aalge in the North Atlantic: geographic impact of oil spills. Mar Ecol Prog Ser 291:263-273

Serreze MC, Holland MM, Stroeve J (2007) Perspectives on the Arctic's shrinking sea ice cover. Science 315: 1533-1536

Sommer JH, Kreft H, Kier G, Jetz W, Mutke J, Barthlott W (2010) Projected impacts of climate change on regional capacities for global plant species richness. Proc Biol Sci 277:2271-2280 
Speakman JR (1997) Doubly labelled water: theory and practice. Chapman and Hall, New York

Stempniewicz L (2001) Alle alle little auk. The Journal of the Birds of the Western Palearctic. Oxford University Press, Oxford. BWP Update 3:175-201

Walczowski W, Piechura J (2006) New evidence of warming propagating toward the Arctic Ocean. Geophys Res Lett 33:L12601, doi: 10.1029/2006GL02587

Welcker J, Harding AMA, Karnovsky NJ, Steen H, Strøm H, Gabrielsen GW (2009a) Flexibility in the bimodal foraging strategy of a high Arctic alcid, the little auk Alle alle. J Avian Biol 40:388-399

Submitted: April 15, 2011; Accepted: January 9, 2012
Welcker J, Harding AMA, Kitaysky AS, Speakman JR, Gabrielsen GW (2009b) Daily energy expenditure increases in response to low nutritional stress in an Arcticbreeding seabird with no effect on mortality. Funct Ecol 23:1081-1090

Wernberg T, Thomsen MS, Tuya F, Kendrick GA, Staehr PA, Toohey BD (2010) Decreasing resilience of kelp beds along a latitudinal gradient: potential implications of a warmer future. Ecol Lett 13:685-694

White GC, Burnham KP (1999) Program MARK: survival estimation from populations of marked animals. Bird Study 46:S120-S139

Proofs received from author(s): March 2, 2012 